\title{
Unsaturated Flow Drying Bed (UFDB): An Alternative for Treatment of Septic Tanks Sludge
}

\author{
Gnagne Théophile ${ }^{1,2 *}$, Yéo Ténénan Martial1,2, Kouamé Yao Francis ${ }^{1,2}$, Konan Koffi Félix ${ }^{2,3}$ \\ ${ }^{1}$ Faculty of Science and Environmental Management, University Nangui Abrogoua, Abidjan, Côte d'Ivoire \\ ${ }^{2}$ Water and Sanitation for Africa, National Representation of Côte d'Ivoire, Abidjan, Côte d'Ivoire \\ ${ }^{3}$ Faculty of Environment, University Jean Lorougnon GUEDE of Daloa, Daloa, Côte d'Ivoire \\ Email: *konanfelix@yahoo.fr
}

Received 29 May 2013; revised 28 June 2013; accepted 15 July 2013

Copyright (C 2014 by authors and Scientific Research Publishing Inc.

This work is licensed under the Creative Commons Attribution International License (CC BY).

http://creativecommons.org/licenses/by/4.0/

(c) (i) 0 pen Access

\begin{abstract}
Unsaturated Flow Drying Bed (UFDB) principles are based on the ones of wastewater treatment by infiltration-percolation on the one hand and septic tanks sludge solar-drying beds on the other hand. With UFDB, sludge charges are split with low heights, leading to the drying of suspended solids in 2 days, and the infiltration of the flow of liquid in unsaturated middle. For average charges reaching $12.5 \mathrm{~cm} / \mathrm{d}$, the treatment efficiency of total oxygen demand and Total Kjeldahl Nitrogen, respectively 95 and $96 \%$, correspond to a treatment capacity of $0.5 \mathrm{~kg} \mathrm{of} \mathrm{O}_{2} / \mathrm{d} / \mathrm{m}^{2}$ of drying area. Bacteria reductions of 4 Ulog are obtained from filtrates outlet, with average fecal coliforms charges less than $103 \mathrm{CFU} / 100 \mathrm{ml}$. Monitoring the hydrodynamic behavior through rates, moisture, organic matter and respiratory activity demonstrates that the clogging of the massifs is linked to a biofilm growth within them. A four week resting period allows biofilm resorption. Thus, the drying of the infiltration surface in two days, the elimination of carbon, nitrogen and bacterial pollutions, as well as the reversibility of clogging show that UFDB is a credible alternative for the treatment of septic tank sludge in the socio-economic context and climate of tropical Africa.
\end{abstract}

\section{Keywords}

Sludge, Clogging, Drying Bed, Unsaturated Zone, Aeration Pores

\footnotetext{
${ }^{*}$ Corresponding author.
} 


\section{Introduction}

In developing countries where most people live on less than 3.263 dollars per year, less than $0.48 \%$ of GDP is devoted to sanitation [1]. In these countries, the coverage rate in service and equipment of sanitation is weak. It's about $25 \%$ in the case of Côte d'Ivoire [2]. Sanitation access is mainly through septic tanks, soak pits or latrines that are used to store sludge [3]. However, the sludge from these in situ sanitations is generally rejected in the wild without prior treatment. This practice has enormous health and environmental risks [4].

Moreover, the climatic conditions of the African continent are characterized by a tropical climate with strong sunning ( 4 hours/day on average), and annual temperatures which oscillate on average between $26^{\circ} \mathrm{C}$ and $28^{\circ} \mathrm{C}$ [5]. In prospect of technologies diversification, we have used methods of sludge treatment based on these climate benefits. The processes most often used are the lagoons, the solar drying bed and the planted bed [4] [6]-[9].

For the lagoon, the sludge circulates through several basins. This leads to the removal of COD of the order of $30 \%$ to $50 \%$, and BOD5 of the order of $60 \%$ to $70 \%$, through the combination of sludge stabilization mechanisms, sedimentation, solid-liquid separation and biochemical reactions [6].

With the solar drying bed, the sludge is continuously discharged on the surface of infiltration forming a layer of 30 to $40 \mathrm{~cm}$ of height. Under these conditions, not only sludge drying takes a long time (six weeks on average), but also the flow of liquid is done in saturated middle with enormous risk of clogging of the infiltration surface and the filtering mass [7] [10] [11]. However, the issue with solar drying bed clogging was attenuated by the adoption of the reed bed whose root systems allow good permeability of the granular mass. In addition, the planted bed technology has the advantage to export nitrogen and phosphorus through the plant [4] [8] [9] [12] [13]. This technology allows for the removal of COD of about $70 \%, \mathrm{BOD}_{5}$ in the range of 60 to 90\% [6] [8] [9], and a reduction of pathogens in the range of $50 \%$ to $60 \%$ [8] [9] [14].

Another improvement can be made through splitting sludge, introduced with low hydraulic charge of $10 \mathrm{~cm}$ maximum per application. This can allow short drying times of suspended solids retained on the surface of infiltration due to high temperature and long duration of sunshine. Thus, after two to three days, suspended solids can be dried and scraped off, releasing the infiltration surface for another feeding. Consequently, the risk of filling the infiltration surface and the filtering mass is minimized. Indeed, splitting charges of sludge introduced induces a flow of water in unsaturated medium. The flow then becomes biphasic, liquid and air. This technology is described as Unsaturated Flow Drying Bed (UFDB).

The aim of this paper is to show that the UFDB constitutes a credible alternative for the treatment of septic tanks sludge in the climatic and socio-economic conditions of the tropical countries of Africa.

\section{Material and Methods}

\subsection{Material}

The material used consists of laboratory analytical equipment and two reactors. Each reactor is made of cylindrical plastic barrel with a height of $103 \mathrm{~cm}$, with $54 \mathrm{~cm}$ inside diameter for a total volume of $200 \mathrm{~L}$ and a lateral surface of $1.2 \mathrm{~m}^{2}$ (Figure 1). The barrels contain, from bottom to top (Figure 1), a perforated PVC drain, a layer of $16 \mathrm{~cm}$ thickness gravels, a geotextile film and a $74 \mathrm{~cm}$ thickness layer of sand $(\mathrm{M}=0.4 \mathrm{~mm})$ with varied granulometry $(\mathrm{CU}=2.35)$. The residual humidity, the humidity with saturation, and the saturated hydraulic conductivity of the sand are respectively $0.05,0.48$ and $0.0172 \mathrm{~cm} / \mathrm{s}$. The barrels are topped with plastic diffusers for uniform distribution of inputs. The Aerated Reactor (AR) is perforated with aeration holes of $2 \mathrm{~mm}$ in diameter on its lateral surface with a density of 6 holes per $\mathrm{dm}^{2}$. The second barrel constitutes the Non Aerated Reactor (NAR).

\subsection{Methods}

\subsubsection{Feeding Reactors}

Feeding is made by short input of about 30 minutes on infiltration surfaces and allowed for two days of rest. The system was followed over a period of 13 months divided between the contributions of five increasing charges $(3.5 \mathrm{~cm} / \mathrm{d}, 5 \mathrm{~cm} / \mathrm{d}, 7.5 \mathrm{~cm} / \mathrm{d}, 10 \mathrm{~cm} / \mathrm{d}$ and $12.5 \mathrm{~cm} / \mathrm{d})$. The passage of one charge to another is marked by a rest period of one month (cessation of feeding of the reactors). 


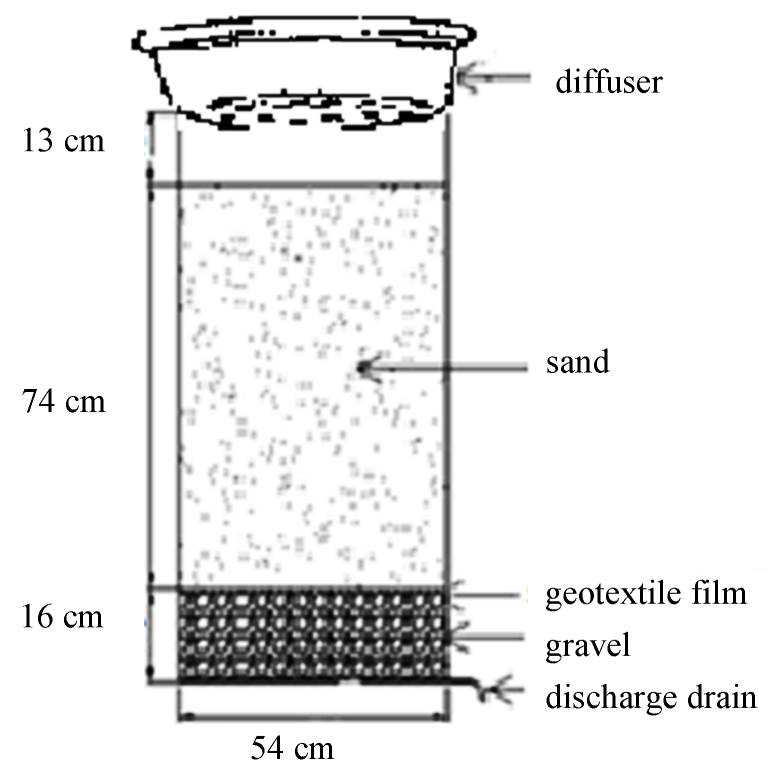

(a)

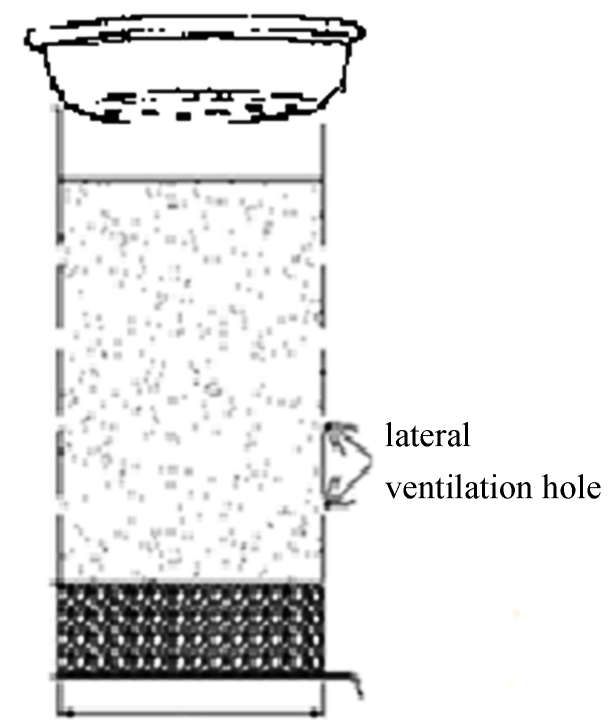

(b)

Figure 1. Schematic representation of Non Aerated Reactor (a) and Aerated Reactor (b).

\subsubsection{Analytical Monitoring}

The parameters considered in this study are: pH, outflow, Ammonium, Nitrate, Total Kjeldahl Nitrogen (TKN), Chemical Oxygen Demand (COD), Humidity, Organic Matter, Respiratory activity of the biomass, Total Oxygen Demand (TOD) and Fecal Coliforms. Table 1 summarizes some measurements and the analytical methods used during the experiments.

\subsubsection{Statistical Analysis}

For the statistical analysis of the data collected, the Mann Whitney pairwise comparison test was conducted to highlight any differences between reactors based on the variables considered. Statistical analyzes were performed with the software Statistic Paleontological (PAST) version 2.15 [21].

\section{Results}

\subsection{Characteristics of Sludge}

The sludge treated in this study has COD concentrations ranging from 700 to $1500 \mathrm{mg} \mathrm{O}_{2} / \mathrm{L}$. For this parameter, a significant difference (Mann-Whitney: $p<0.05$ ) is observed only between the charge $3.5 \mathrm{~cm} / \mathrm{d}$ and charges 10 and $12.5 \mathrm{~cm} / \mathrm{d}$ (Figure 2(a)).

The TKN values ranged from 400 to $1000 \mathrm{mg} / \mathrm{L}$. For this parameter, significant differences (Mann-Whitney: $p<0.05$ ) were observed between the charge $7.5 \mathrm{~cm} / \mathrm{d}$ and those of $10 \mathrm{~cm} / \mathrm{d}$ and $12.5 \mathrm{~cm} / \mathrm{d}$ on the one hand, and between the charge $10 \mathrm{~cm} / \mathrm{d}$ and that of $12.5 \mathrm{~cm} / \mathrm{d}$ on the other hand (Figure 2(b)).

\subsection{Treatment Efficiency of the Reactors}

Throughout the period of monitoring reactors, the removal efficiencies of the total oxygen demand (TOD) of the Non Aerated Reactor range from 98 to $94 \%$ according to the different treated polluting charges. The mean values of the TOD of the effluent leaving the Non Aerated Reactor vary from 89 to $245 \mathrm{mg} \mathrm{O} / \mathrm{L}$. The Non Aerated Reactor has also less acidic $\mathrm{pH}$ (5.2) compared with Aerated Reactor whose $\mathrm{pH}$ stabilize at more acidic values (3.3). The removal efficiencies of the TOD of the Aerated Reactor vary from 98 to $96 \%$. This reactor restores the TOD to average values from 100 to $180 \mathrm{mg} \mathrm{O}_{2} / \mathrm{L}$. In addition, reductions in fecal coliforms in the range of 3.5 to $4.6 \mathrm{ULog}$ are obtained for both reactors (Table 2).

For hydraulic loads below $10 \mathrm{~cm} / \mathrm{d}$, values of $\mathrm{pH}$ TKN and $\mathrm{NO}_{3}^{-}$filtrates obtained were not significantly different (Mann Whitney test: $p>0.05$ ) from one reactor to another (Figure 3). The removal efficiencies of 


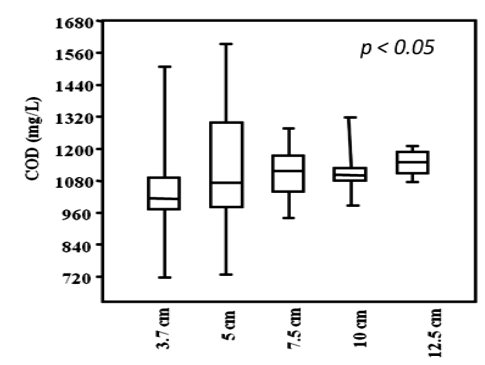

(a)

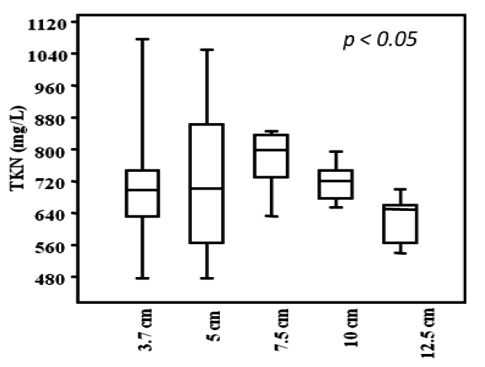

(b)

Figure 2. Variation of COD (a) and TKN (b) of sludge at different applied charges. $\mathrm{p}=$ significance level of Kruskal-Wallis non parametric test.
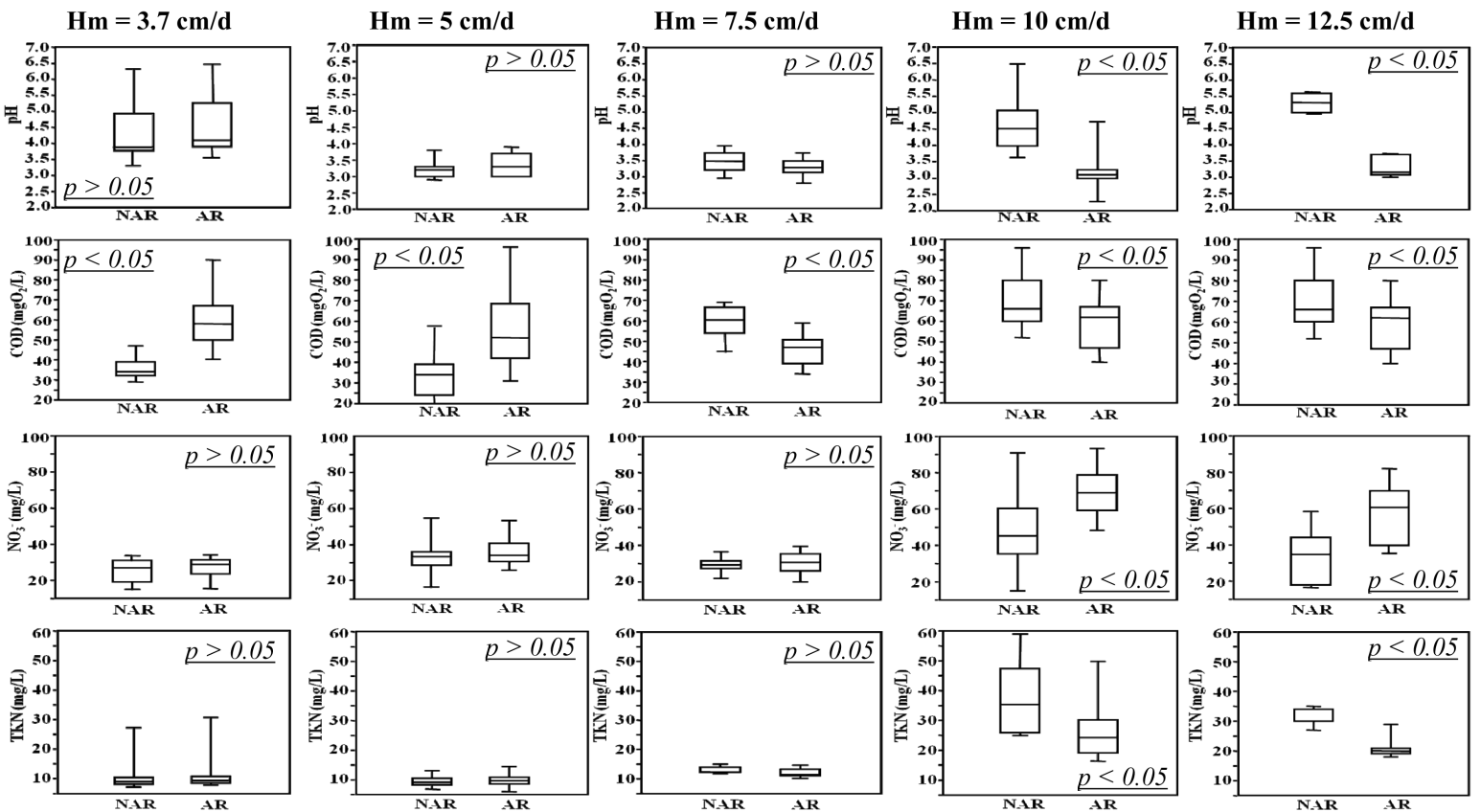

Figure 3. Variation of physicochemical parameters of Non Aerated Reactor (NAR) and Aerated Reactor (AR) to different hydraulic charges averages. $\mathrm{Hm}=$ average hydraulic charges. $p=$ significance level of Mann-Whitney non parametric test.

COD are significant to the Non Aerated Reactor at the level of charges $3.5 \mathrm{~cm} / \mathrm{d}$ and $5 \mathrm{~cm} / \mathrm{d}$. For charges 10 $\mathrm{cm} / \mathrm{d}$ and $12.5 \mathrm{~cm} / \mathrm{d}$, the Aerated Reactor provides the best removal efficiencies of COD and TKN, the lowest $\mathrm{pH}$ values and highest concentrations of $\mathrm{NO}_{3}^{-}$(of about $70 \mathrm{mg} / \mathrm{L}$ ) (Figure 3).

\subsection{Monitoring Output Flows}

During feeding reactors with clear water at charge $3.5 \mathrm{~cm} / \mathrm{d}$, outflow of each reactor are identical throughout the test period (Figure 4). The results of the first days are the same as the 15 th and 30th days of feeding. The maximum outflow (Qmax) at this charge is $7.08 \mathrm{~cm}^{3} / \mathrm{s}$ for Aerated Reactor and $10.02 \mathrm{~cm}^{3} / \mathrm{s}$ for Non Aerated Reactor.

In contrast, with sludge, outflows decrease with time (Figure 5). For Aerated Reactor, at the charge of 3.5 $\mathrm{cm} / \mathrm{d}$, the Qmax stabilizes to $4.08 \mathrm{~cm}^{3} / \mathrm{s}$ after three months of operation, which is equivalent to a reduction of $42.40 \%$ of outflow. For Non Aerated Reactor, outflow stabilizes to $3.91 \mathrm{~cm}^{3} / \mathrm{s}$ after three months of operation, equivalent to a reduction of $56.55 \%$. When the charge increases to $5 \mathrm{~cm} / \mathrm{d}$, the Qmax stabilizes to $5.20 \mathrm{~cm}^{3} / \mathrm{s}$ for Aerated Reactor and $4.66 \mathrm{~cm}^{3} / \mathrm{s}$ for the Non Aerated Reactor. These values correspond respectively to $54.33 \%$ and $58.10 \%$ of reductions of outflow. At the charge of $7.5 \mathrm{~cm} / \mathrm{d}$, the output rates are estimated to $11.52 \mathrm{~cm}^{3} / \mathrm{s}$ for Aerated Reactor and $10.95 \mathrm{~cm}^{3} / \mathrm{s}$ for Non Aerated Reactor. The reductions of outflows are of about $56 \%$ and 
Table 1. Summary of methods used to analyze physicochemical and microbiological parameters [15]-[20].

\begin{tabular}{|c|c|}
\hline Parameters & Methods of analysis \\
\hline $\mathrm{pH}$ & $\begin{array}{l}\text { In situ measurement using } \mathrm{HACH} \text { pH meter EC 10. Electrochemical with glass electrode } \\
\text { (NF T 90-008) [17]. }\end{array}$ \\
\hline Debit & Instantaneous measurement of volumes restored and their time of appearance \\
\hline Ammonium & Spectrophotometric indophenol blue method (NF T 90-015) [17]. \\
\hline Nitrate & Spectrophotometric sodium salicylate method (NF T 90-045) [17]. \\
\hline Total Kjeldahl Nitrogen (TKN) & Method after mineralization with selenium (NF T 90-010) [17]. \\
\hline Chemical Oxygen Demand (COD) & Potassium dichromate oxidizability Method (NF T 90-101) [17]. \\
\hline Humidity & $\begin{array}{c}\text { Difference in mass of the sample before and after drying at } 105^{\circ} \mathrm{C} \text { divided by the mass of the } \\
\text { sample [16] }\end{array}$ \\
\hline Organic Matter & Difference in sample mass between $105^{\circ}$ and $550^{\circ} \mathrm{C}$ divided by the sample mass [19] \\
\hline Respiratory activity of the biomass & Trapping $\mathrm{CO}_{2}$ in sodium hydroxide Method [20]. \\
\hline Fecal Coliforms & $\begin{array}{l}\text { Isolation of fecal coliforms by incorporation in Eosin Methylene Blue (EMB) Method } \\
\text { (NF T90-416) [17]. }\end{array}$ \\
\hline Total Oxygen Demand (TOD) & $\begin{array}{c}\text { TOD is deduced from the concentration of COD and NTK using the following equation: DTO } \\
=\text { DCO }+4.57 \text { NTK }[15] .\end{array}$ \\
\hline
\end{tabular}

Table 2. Treatment performance of reactors according hydraulic charges applied.

\begin{tabular}{|c|c|c|c|c|c|c|}
\hline & \multirow[b]{2}{*}{ Reactor } & \multicolumn{5}{|c|}{ Treatment efficiency (\%) at different Hydraulic charges } \\
\hline & & $3.7 \mathrm{~cm} / \mathbf{j}$ & $5 \mathrm{~cm} / \mathbf{j}$ & $7.5 \mathrm{~cm} / \mathbf{j}$ & $10 \mathrm{~cm} / \mathbf{j}$ & $12.5 \mathrm{~cm} / \mathrm{j}$ \\
\hline \multirow{2}{*}{ NTK } & RNA & 98.36 & 98.68 & 98.33 & 94.67 & 95 \\
\hline & RA & 98.31 & 98.63 & 98.45 & 96.32 & 96.67 \\
\hline \multirow{2}{*}{ COD } & RNA & 96.60 & 97 & 94.50 & 93.60 & 93.40 \\
\hline & RA & 94.40 & 95 & 96 & 94.60 & 95 \\
\hline \multirow{2}{*}{ TOD } & RNA & 98.00 & 98.30 & 97.44 & 94.41 & 94.58 \\
\hline & RA & 97.37 & 97.67 & 97.83 & 95.89 & 96.15 \\
\hline \multirow{2}{*}{$\begin{array}{l}\text { Fecal colifom } \\
\text { (ULog) }\end{array}$} & RNA & 3.65 & 4.03 & 3.63 & 4.02 & 4.17 \\
\hline & RA & 3.52 & 3.99 & 3.83 & 4.13 & 4.59 \\
\hline
\end{tabular}
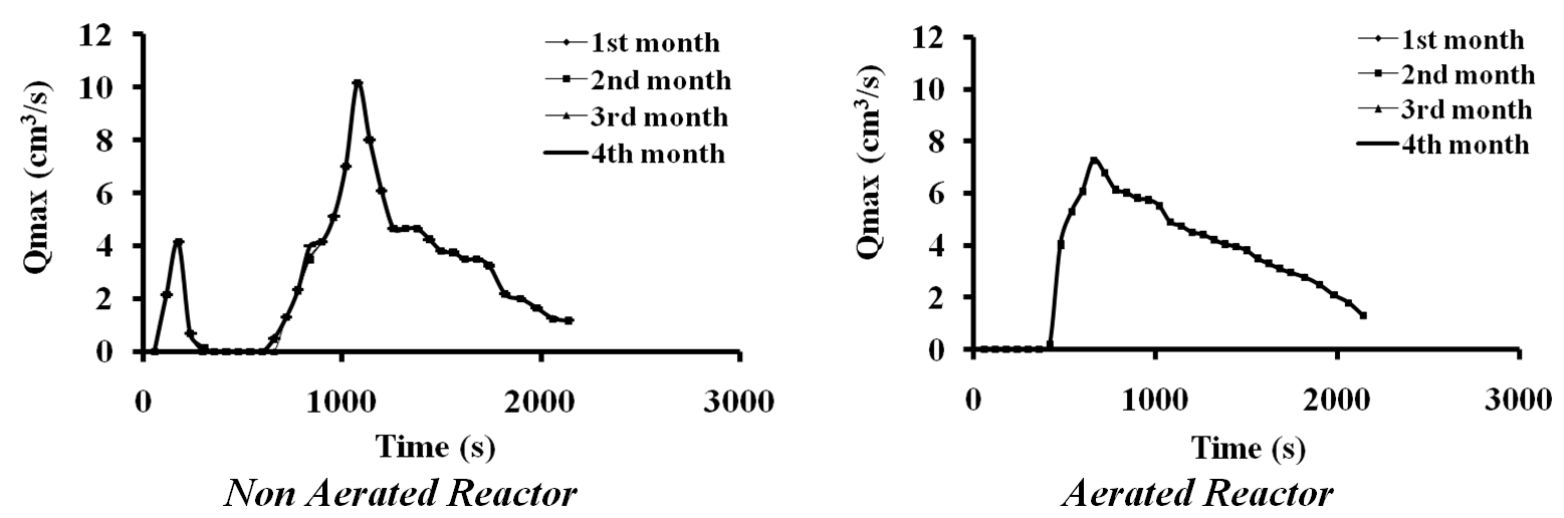

Figure 4. Variation of outflow rate (Qmax) with clean water of the reactors over time. 


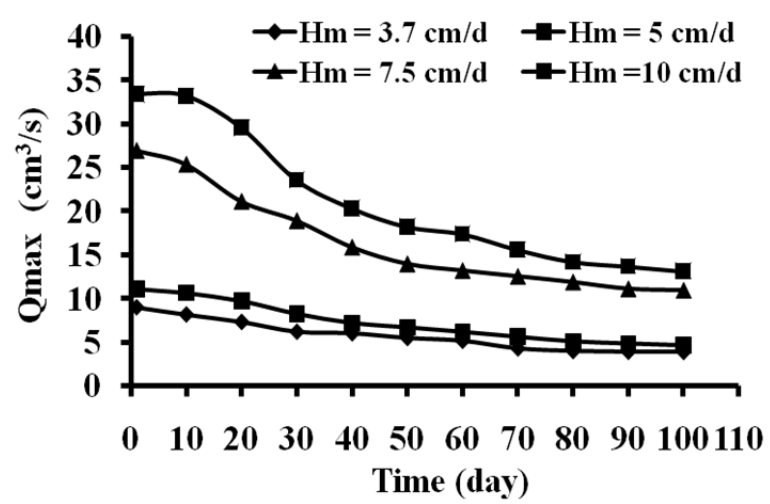

Non Aerated Reactor

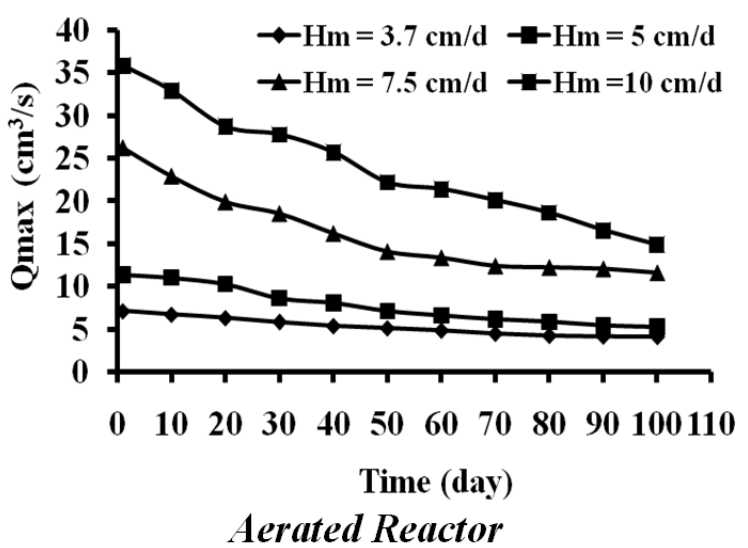

Figure 5. Variation of outflow rate (Qmax) of reactors according to hydraulic charges applied.

$59.30 \%$ respectively. At $10 \mathrm{~cm} / \mathrm{d}$, the outflows are stabilizing at $14.82 \mathrm{~cm}^{3} / \mathrm{s}$ for Aerated Reactor and 13.12 $\mathrm{cm}^{3} / \mathrm{s}$ for Non Aerated Reactor. Reductions of outflows are respectively equal to $58.60 \%$ and $60.74 \%$.

\subsection{Organic Matter}

After three months of functioning, the essential of organic matter is accumulated in the first five centimeters of the reactors. The accumulations of organic matter in the filter beds are $43.52 \mathrm{mg} / \mathrm{g}$ of sand in Aerated Reactor and $53.33 \mathrm{mg} / \mathrm{g}$ of sand in Non Aerated Reactor for the hydraulic charge equal to $3.5 \mathrm{~cm} / \mathrm{d}$ (Figure 6). When hydraulic charge increases to $5 \mathrm{~cm} / \mathrm{d}$, the accumulation rate of organic matter passes to $49.56 \mathrm{mg} / \mathrm{g}$ of sand for Aerated Reactor and $58.76 \mathrm{mg} / \mathrm{g}$ of sand Non Aerated Reactor. At charge $7.5 \mathrm{~cm} / \mathrm{d}$, the organic matter rate increases to $56.54 \mathrm{mg} / \mathrm{g}$ of sand for the Aerated Reactor, and $64.75 \mathrm{mg} / \mathrm{g}$ of sand for Non Aerated Reactor. For the hydraulic charge equal to $10 \mathrm{~cm} / \mathrm{d}$, the organic matters go to $61.57 \mathrm{mg} / \mathrm{g}$ of sand and $77.59 \mathrm{mg} / \mathrm{g}$ of sand respectively in Aerated Reactor and Non Aerated Reactor.

\subsection{Respiratory Activity of Microorganisms in the Filter Bed}

The results of the biomass respiratory activity of contained in the filter bed during the feeding phases showed that most of the $\mathrm{CO}_{2}$ is produced in the first five centimeters of filter bed (Figure 7).

After three months of functioning under the hydraulic charge of $3.5 \mathrm{~cm} / \mathrm{d}$, we found a rate of $0.25 \mathrm{mg} \mathrm{CO} / \mathrm{g}$ of sand in the Aerated Reactor and $0.3 \mathrm{mg} \mathrm{CO} / \mathrm{g}$ of sand in the Non Aerated Reactor. At hydraulic charge of 5 $\mathrm{cm} / \mathrm{d}$, we collected a $\mathrm{CO}_{2}$ level of $0.295 \mathrm{mg} / \mathrm{g}$ of sand in the Aerated Reactor, and $0.398 \mathrm{mg} / \mathrm{g}$ of sand in the Non Aerated Reactor. Under the hydraulic charge of $7.5 \mathrm{~cm} / \mathrm{d}$, the $\mathrm{CO}_{2}$ recorded in Aerated Reactor and Non Aerated Reactor is respectively $0.387 \mathrm{mg} / \mathrm{g}$ of sand and $0.48 \mathrm{mg} / \mathrm{g}$ of sand. When the charge increases to $10 \mathrm{~cm} / \mathrm{d}$, the $\mathrm{CO}_{2}$ rate moved to $0.498 \mathrm{mg} / \mathrm{g}$ of sand for the Aerated Reactor and $0.615 \mathrm{mg} / \mathrm{g}$ of sand for the Non Aerated Reactor.

Furthermore, when the reactors are laid to rest after running under hydraulic charges $3.5 \mathrm{~cm} / \mathrm{d}, 5 \mathrm{~cm} / \mathrm{d} .7 .5$ $\mathrm{cm} / \mathrm{d}$ and $10 \mathrm{~cm} / \mathrm{d}$ the $\mathrm{CO}_{2}$ levels falls to $0 \mathrm{mg} / \mathrm{g}$ sand for two reactors after respectively one, two, three and four weeks of rest.

\section{Discussion}

This study was devoted to the treatment of sludge from septic tanks by Unsaturated Flow Drying Bed (UFDB), in climatic and socio-economic conditions of the tropical countries of Africa.

The results show that for hydraulic charges below $10 \mathrm{~cm} / \mathrm{d}$ there is no difference in treatment efficiency of sludge from the aerated reactor and unventilated reactor. For the charge $10 \mathrm{~cm} / \mathrm{d}$ and $12.5 \mathrm{~cm} / \mathrm{d}$, the aerated reactor has the highest yields with discharges of COD and TKN respectively about $60 \mathrm{mg} \mathrm{O} 2 / \mathrm{L}^{2} \mathrm{and} 40 \mathrm{mg} \mathrm{O} / \mathrm{L}$ compared to unventilated reactor. This shows that we need more oxygen to degrade the additional pollution related to the augmentation of manageable hydraulic charge [20].

In aerated reactor, the additional oxygen is brought by lateral ventilation, which is not the case for the unven- 


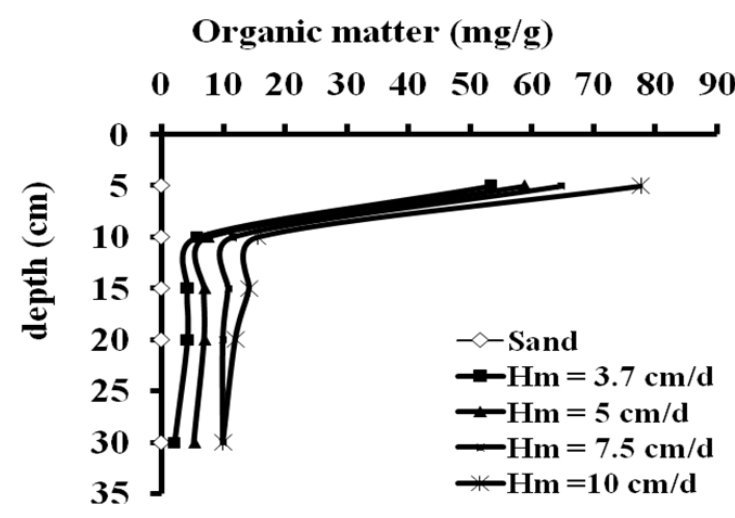

Non Aerated Reactor
Organic matter $(\mathbf{m g} / \mathbf{g})$

$\begin{array}{llllllllll}0 & 10 & 20 & 30 & 40 & 50 & 60 & 70 & 80 & 90\end{array}$

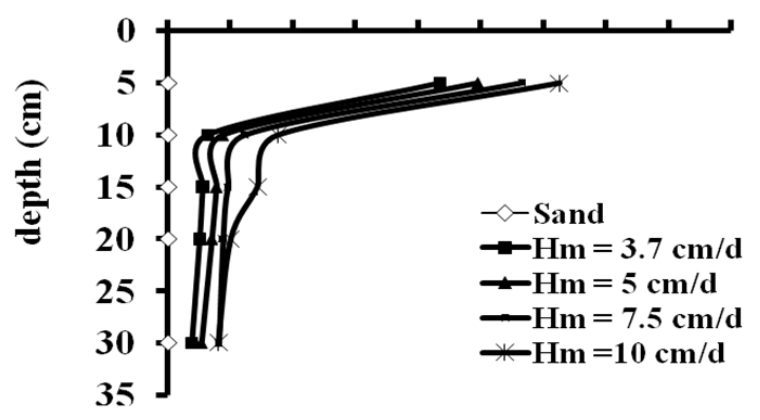

Aerated Reactor

Figure 6. Variation of organic matter in the filter beds of reactors according to hydraulic charges applied.

$$
\mathrm{CO}_{2}(\mathrm{mg} / \mathrm{mg})
$$

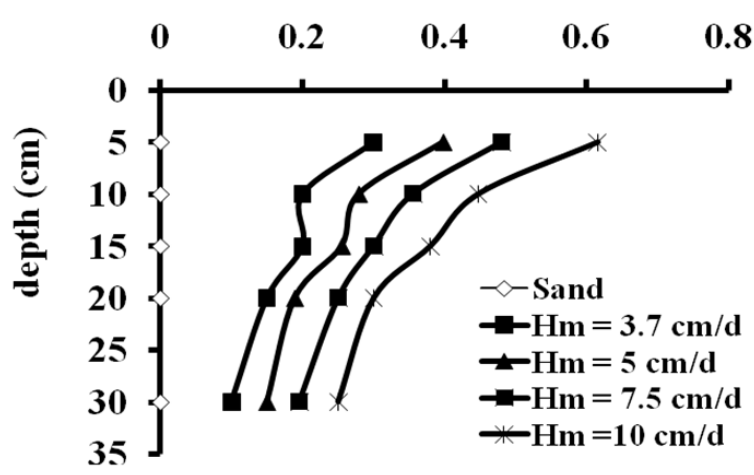

Non Aerated Reactor
$\mathrm{CO}_{2}(\mathrm{mg} / \mathrm{mg})$

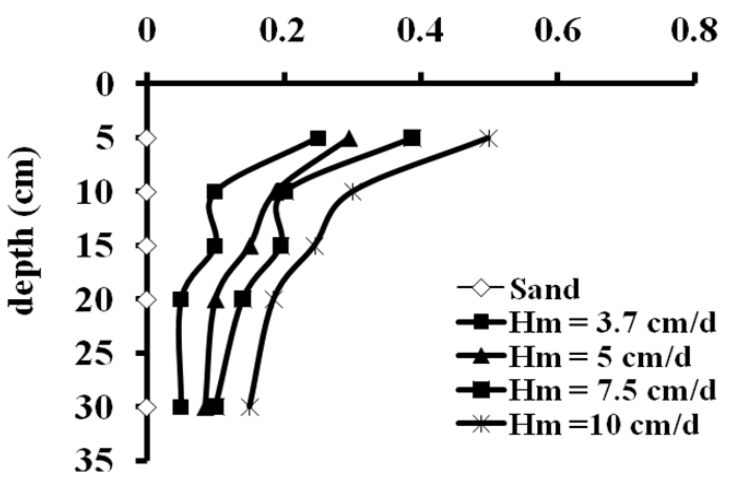

Aerated Reactor

Figure 7. Variation of $\mathrm{CO}_{2}$ in the filter beds of reactors according to hydraulic charges applied.

tilated reactor. The difference in oxygenation is also measured through the difference in $\mathrm{pH}$ which is more acid (3.2) for a better oxidation in RA, while it is less acid (5.3) for a worse oxidation in unventilated reactor. Indeed, to the hydraulic loads of $3.5 \mathrm{~cm} / \mathrm{d}, 5 \mathrm{~cm} / \mathrm{d}$ and $7.5 \mathrm{~cm} / \mathrm{d}$, the $\mathrm{pH}$ at exit of the two reactors are acid. This shows good oxidation reaction as [22] have observed in the case of slightly alkaline wastewater with high organic charges, where the fall of the $\mathrm{pH}$ is related to the acidifying tendency of biological oxidation reactions of carbon and nitrogen.

Thus, for the hydraulic charges below $10 \mathrm{~cm} / \mathrm{d}$, the oxygen supplied is sufficient. Indeed, under these charges, the fractional contributions keep pollution in the first centimeters of filter bed [23]. Under these conditions, aeration by diffusion through the infiltration surface, due to two rest days, allows oxygen to reach all the pollution in the two reactors.

This is not the case for the $10 \mathrm{~cm} / \mathrm{d}$ and $12.5 \mathrm{~cm} / \mathrm{d}$ charges, where pollution penetrates deeper. In fact, with a hydraulic charge equal to twice the average of hydraulic charge, pollution is accumulated more than $50 \mathrm{~cm}$ deep in the filter bed composed of sand with porosity 0.4 . Under these conditions, the two days rest were not enough for diffusive oxygen through the infiltration surface, reaching down pollution in the case of Non Aerated Reactor [24].

In contrast, at the aerated reactor, the diffusive ventilation through the lateral surface provides the oxygen necessary for the degradation of pollution in button, so that the elimination of pollution of the Aerated Reactor is better than that of Non Aerated Reactor. Moreover, the $\mathrm{pH}$ of the effluent at the outlet of the aerated reactor is more acidic than that of the Non Aerated Reactor. This reflects better oxygenation of the Aerated Reactor compared to Non Aerated Reactor to these charges. 
The results also show a strong nitrogen removal with a yield of over $96 \%$. Indeed, fractional inputs of septic tanks sludge allows the mixing of wastewaters of different ages, and the coexistence of aerobic areas and anaerobic areas in the Unsaturated Flow Drying Bed (UFDB). The long periods of rest allow the oxidation of nitrogen. Thus, the new water rich in carbon, brought during feeding, mixes with the old water, rich in nitrate, formed during the rest phases [22] [25]. Furthermore, the nonhomogeneous aeration of the filter bed of the UFDB favors the existence of aerobic and anaerobic zones from the periphery to the center of this type of reactor [26]. These conditions which are met in the case of UFDB, explain the coexistence of nitrification and denitrification to provide the biological removal of nitrogen [27]-[31].

From the hydrodynamic, results of tests with clear water for a period of 30 days showed that the output flows of the reactors do not vary. Contrariwise, these flows decrease in the course of feeding with sludge from septic tanks. For each reactor, the reduction is even more important than the applied hydraulic charge is high. The element that differs in both cases is the quality of the effluent provided (water and sludge from septic tanks). Thus, lower output rates can be explained with sludge from septic tanks, by reducing the hydraulic conductivity due to the reduction of the pore space caused by the establishment and growth of the biofilm [16] [32]. This is highlighted by the results of organic matter on the one hand, and respiratory activity on the other hand. Indeed, after three months of supplying, the rate of organic matter grows from $0 \mathrm{mg} / \mathrm{g}$ to $43.52 \mathrm{mg} / \mathrm{g}$ in the case of aerated reactor, and from $0 \mathrm{mg} / \mathrm{g}$ to $53.33 \mathrm{mg} / \mathrm{g}$ in one of Non Aerated Reactor.

The biological nature of this organic matter is revealed by the respiratory activity of biofilm measured by the vertical profile of $\mathrm{CO}_{2}$ levels. The highest values are measured in the first five centimeters, where there is a large accumulation of organic matter. Moreover, the setting at rest of the reactors allows the reduction of the organic matter, and the cessation of production of $\mathrm{CO}_{2}$. Indeed, after a month of rest, the rate of organic matter increases from $43.52 \mathrm{mg} / \mathrm{g}$ of sand to $7 \mathrm{mg} / \mathrm{g}$ of sand for the Aerated Reactor, and $53.33 \mathrm{mg} / \mathrm{g}$ of sand to $13 \mathrm{mg} / \mathrm{g}$ sand for the Non Aerated Reactor. This fact not only denotes the organic nature of the elimination of carbonaceous and nitrogenous pollution by UFDB, but also the reversibility of the UFDB filter bed clogging [20].

\section{References}

[1] UN Water (2010) Première partie: priorités, Ciblage et adéquation des Flux Financiers. Evaluation annuelle mondiale de l'ONU-Eau sur l'assainissement et l'eau potable.

[2] DSRP (2009) Document stratégique de relance du développement et de réduction de la pauvreté. République de Côte d'Ivoire.

[3] Strauss, M. and Montangero, A. (2001) Gestion des boues de vidange. Institut Fédéral pour l'aménagement, l'épuration et la protection des eaux (EAWAG), BP 611, CH 8600 Duebebdarf Suisse.

[4] Florian, K., Agnès, M., Koné, D. and Strauss, M. (2002) Gestion des boues de vidange dans les pays en développement, Manuel de planification. Institut de Recherche sur l'Eau du Domaine des Ecoles Polytechniques Fédérales (EAWAG), Département Eau et assainissement dans les pays en développement (SANDEC).

[5] Goula, B.T.A., Savané, I., Konan, B., Fadika, V. and Kouadio, G.B. (2006) Impact de la variabilité climatique sur les ressources hydriques des bassins de N'zo et N'zi en Côte d'Ivoire (Afrique tropicale humide). Vertigo, 1, 1-12.

[6] Koné, D. and Strauss, M. (2004) Performances et Challenges des techniques de traitement à faible coût des boues de vidange. SANDEC, Institut fédéral suisse pour l'aménagement, l'épuration et la protection des eaux (EAWAG).

[7] Mungray, A.K. and Kumar, P. (2007) Degradation of Anionic Surfactants during Drying of UASBR Sludges on Sand Drying Beds. Journal of Environmental Management, 88, 995-1002.

[8] Ouattara, P.J.M., Coulibaly, L., Manizan, N.P. and Gourène, G. (2008) Traitement des eaux résiduaires urbaines par un marais artificiel à drainage vertical planté avec Panicum maximum sous climat tropical. European Journal of Scientific Research, 23, 25-40.

[9] Ouattara, P.J.M., Coulibaly, L., Tiho, S., Ouattara, A. and Gourène, G. (2011) Panicum Maximum (Jacq.) Density Effect upon Macrofauna Structure in Sediments of Pilot-Scale Vertical Flow Constructed Wetlands Treating Domestic Wastewater. Ecological Engineering, 37, 217-223. http://dx.doi.org/10.1016/j.ecoleng.2010.10.002

[10] DEGREMONT (1989) Mémento technique de l'eau. Edition du cinquantenaire, $9^{\text {ème }}$ edition, Tome 1.

[11] Agence de l'Eau (1992) Influence de la granulométrie du matériau filtrant par infiltration percolation. Etude inter agences $\mathrm{n}^{\circ} 8$, Office international de l'eau, Paris.

[12] Brouillet, J.L., Picot, B., Sambuco, J.P., Gaillard, L., Soteras, G. and Valarié, I. (2008) Ecotechniques d'assainissement des eaux usées domestiques: évolution et perspectives. XIII ${ }^{\mathrm{e}}$ Congrès Mondial de l'Eau, $1^{\mathrm{er}}$ au 4 septembre 2008, Montpellier. 
[13] Alain, L. (1999) Déshydratation de boues par lits de séchage plantés de roseaux. Conférences internationales sur les marais artificiels et le lagunage pour le traitement des eaux usées. CEMAGREF Lyon.

[14] Agnès, M. and Martin, S. (2002) Gestion des boues de vidange. Institut fédéral pour l'aménagement, l'épuration et la protection des eaux, Département Eau et Assainissement dans les pays en développement, Duebendorf, Suisse.

[15] Sachon, G. (1986) Les eaux usées résiduaires des abattoirs de bétail: gestion et traitement. Tribune Cebedeau, 516, $27-45$.

[16] Musy, A. and Soutter, M. (1991) Physique du sol. CH-1015 Lausanne, collection META.

[17] AFNOR (1994) Qualité de l'eau. Environnement, Association française de normalization. 1st Edition, AFNOR, Paris.

[18] Rodier, C. (1996) Le phosphore dans les sols et dans les milieux aquatiques. Transfert des polluants dans les hydrosystèmes, Presse de l'ENPC, Paris.

[19] CEAEQ (2005) Détermination du phosphore total dans les eaux naturelles: Minéralisation au persulfate; méthode colorimétrique automatisée; procédures adaptées pour le phosphore en teneur élevée et à l'état de trace. MA. 303-P 5.0, $1^{\text {ère }}$ rév., Centre d'expertise en analyse environnementale du Québec, Ministère du Développement durable, de l'Environnement et des Parcs du Québec.

[20] Menoret, C. (2001) Traitement d'effluents concentrés par cultures fixées sur gravier ou pouzzolane. Thèse de doctorat de l'Université des Sciences du Languedoc, Montpellier II.

[21] Hammer, O., Harper, D.A.T. and Ryan, P.D. (2001) Paleontological Statistics Software Package for Education and Data Analysis. Paleontologica Electronica, 4, 1-9.

[22] Gnagne, T., Brissaud, F. and Houenou, P.V. (2007) Possibilités d'utilisation du ph pour le suivi de l'efficacité épuratoire des eaux usées peu alcaline fortement chargées en matières oxydables en épuration par infiltration sur sable. Journal de la Société Ouest-Africaine de Chimie, 24, 85-92.

[23] Gnagne, T. and Brissaud, F. (2003) Etude des potentialités d'épuration d'effluent d'abattoir par infiltration sur sable en milieu tropical. Sud Science et Technologie, 11, 4-11.

[24] Wanko, A. (2005) Etude des mécanismes de transfert et evaluation des capacités d'oxygénation et de traitement des dispositifs par cultures fixées sur support granulaire fin. Thèse de doctorat N99026201, Ecole doctorale MSH, Mathématiques et Sciences de l'information et de l'ingénieur, CEMAGREF.

[25] Kouamé, Y.F., Yéo, T.M., Gnagne, T., Konan, K.F., N'Gouandi, K.F., Yapo, O.B., Séka, A. and Houénou, P.V. (2010) Stratégie d'élimination de l'azote des boues de vidange par Lit de Séchage à Ecoulement Non Saturé (LSENS). Journal de la Société Ouest-Africaine de Chimie, 29, 1-10.

[26] Yéo, T.M., Gnagne, T., Konan, K.F., Kouamé, Y.F. and Houenou, P.V. (2008) Etude de la vulnérabilité d'un lit de séchage d'effluents de fosses septiques à écoulement non saturé. European Journal of Scientific Research, 24, 187-196.

[27] Lefevre, F. (1988) Epuration des eaux usées par infiltration percolation: Etude expérimentale et définition du procède. Thèse en Sciences de l'Eau et Aménagement. Université des Sciences du Languedoc, Montpellier II.

[28] Guilloteau, J.A. (1992) Traitement des eaux résiduaires par infiltration percolation: Performances, biomasse et renouvellement des gaz. Thèse de doctorat, Spécialité Sciences et technique de l'eau, Université Louis Pasteur de Strasbourg.

[29] Page, S., Hénault, C., Chéneby, D., Lagacherie, D. and Germon, J.C. (1998) Devenir de l'azote des eaux résiduaires de féculerie après épandage sur un sol cultivé. Etude et Gestion des Sols, 5, 117-133.

[30] Helmer, C., Kunst, S., Juretschko, S., Schid, M.C., Schleifer, K.H. and Wagner, M. (1999) Nitrogen Loss in a Nitrifying Biofilm System. Water Science andTechnology, 39, 13-21. http://dx.doi.org/10.1016/S0273-1223(99)00145-6

[31] Gupta, A.B. and Gupta, S.K. (2001) Simultaneous Carbon and Nitrogen Removal from High Strength Domestic Wastewater in an Aerobic RBC Biofilm. Water Research, 35, 1714-1722. http://dx.doi.org/10.1016/S0043-1354(00)00442-5

[32] Castany, G. (1989) Hydrogéologie: Principes et Méthodes. Aubin-LIGUGE, Poitiers. 